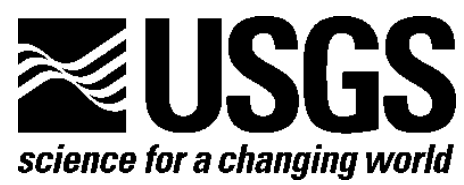

Prepared in cooperation with the U.S. Department of Energy

\title{
Stochastic Modeling of a Lava-Flow Aquifer System
}

By C. Cronkite-Ratcliff and G.A. Phelps

Open-File Report 2014-1179

U.S. Department of the Interior

U.S. Geological Survey 


\section{U.S. Department of the Interior \\ SALLY JEWELL, Secretary}

\section{U.S. Geological Survey \\ Suzette M. Kimball, Acting Director}

U.S. Geological Survey, Reston, Virginia: 2014

For more information on the USGS—-the Federal source for science about the Earth, its natural and living resources, natural hazards, and the environment-visit

http://www.usgs.gov or call 1-888-ASK-USGS

For an overview of USGS information products, including maps, imagery, and publications, visit $h$ ttp://www.usgs.gov/pubprod

To order this and other USGS information products, visit http://store.usgs.gov

Suggested citation:

Cronkite-Ratcliff, C., and Phelps, G.A., 2014, Stochastic modeling of a lava-flow aquifer system: U.S. Geological Survey Open-File Report 2014-1179, 18 p., http://dx.doi.org/10.3133/ofr20141179.

Any use of trade, firm, or product names is for descriptive purposes only and does not imply endorsement by the U.S. Government.

Although this information product, for the most part, is in the public domain, it also may contain copyrighted materials as noted in the text. Permission to reproduce copyrighted items must be secured from the copyright owner.

ISSN 2331-1258 (online) 


\section{Contents}

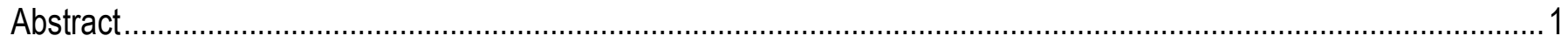

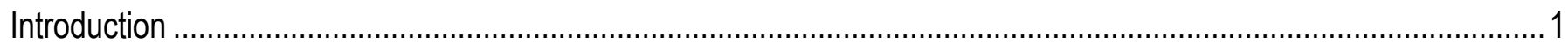

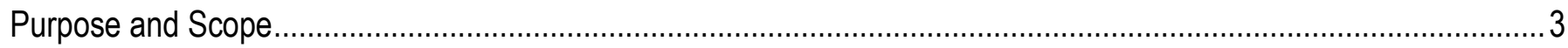

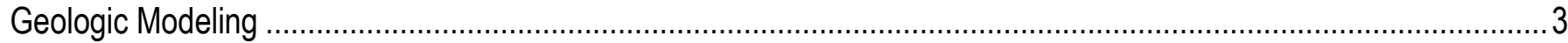

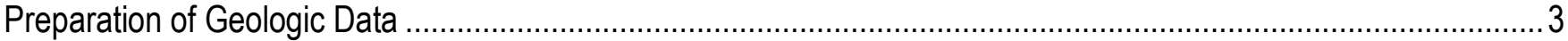

Training Image.

Realizations

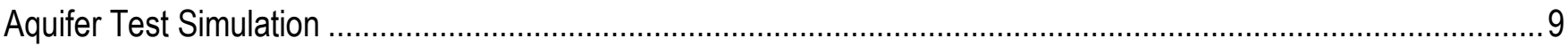

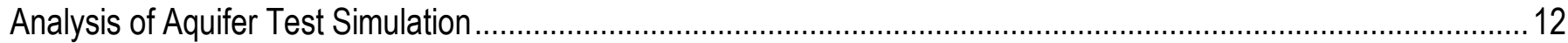

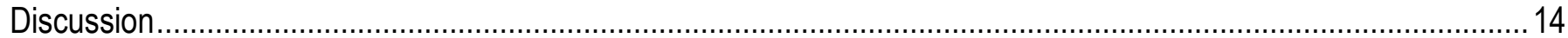

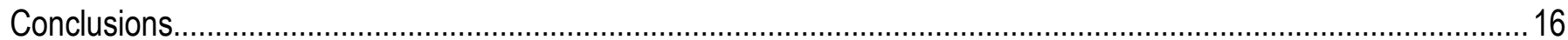

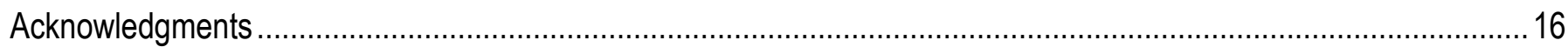

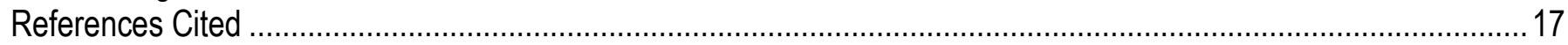

\section{Figures}

1. Map showing location of the study region and boreholes in Pahute Mesa, Nevada, located within the Nevada National Security Site (NNSS); horizontal coordinates are referenced to NAD83.

2. Three-dimensional image of the study region, showing the full vertical extent of the Calico Hills Zeolitic Composite Unit and geologic data from the 21 boreholes that penetrate the Calico Hills Zeolitic Composite Unit within the study region.

3. Three-dimensional image of the training image, showing two-dimensional cross-sections from two slices along the vertical planes $A-A^{\prime}$ and $B-B^{\prime}$

4. Three-dimensional images of 4 of the 1,000 realizations generated using multiple-point geostatistical simulation.... 8

5. Three-dimensional image of the subregion used for simulation of the aquifer test, showing the location of the subregion within the study region, the pumping well (U-20 WW), and the observation well (ER-20-6 \#3).......9

6. Three-dimensional images of four realizations generated using multiple-point geostatistical simulation, showing cells located only within the subregion.

7. Discretization of the MODFLOW grid used for groundwater flow simulation, showing the area corresponding to the subregion of the geostatistical model (outlined with the thick line).

8. Graphs showing simulated drawdown and estimated drawdown by Garcia and others (2011) in well ER-20-6 \#3;

(a) shows realizations where the pumping zone in well U-20 WW is connected to the observation zone in well ER-20-6 \#3 by a path of adjacent grid cells with lava flow hydrofacies; (b) shows realizations where these two zones are not connected.

\section{Tables}

1. Hydraulic properties used in the aquifer test simulation.

2. Stress periods and status of pumping well in the aquifer test simulation. 


\section{Conversion Factors}

SI to Inch/Pound

\begin{tabular}{|c|c|c|}
\hline Multiply & By & To obtain \\
\hline \multicolumn{3}{|c|}{ Length } \\
\hline meter (m) & 3.281 & foot $(\mathrm{ft})$ \\
\hline kilometer (km) & 0.6214 & mile (mi) \\
\hline \multicolumn{3}{|c|}{ Volume } \\
\hline cubic meter $\left(\mathrm{m}^{3}\right)$ & 264.2 & gallon (gal) \\
\hline cubic meter $\left(\mathrm{m}^{3}\right)$ & 35.31 & cubic foot $\left(\mathrm{ft}^{3}\right)$ \\
\hline \multicolumn{3}{|c|}{ Flow rate } \\
\hline cubic meter per day $\left(\mathrm{m}^{3} / \mathrm{d}\right)$ & 35.31 & cubic foot per day $\left(\mathrm{ft}^{3} / \mathrm{d}\right)$ \\
\hline cubic meter per day $\left(\mathrm{m}^{3} / \mathrm{d}\right)$ & 264.2 & gallon per day (gal/d) \\
\hline \multicolumn{3}{|c|}{ Hydraulic conductivity } \\
\hline meter per day $(\mathrm{m} / \mathrm{d})$ & 3.281 & foot per day $(\mathrm{ft} / \mathrm{d})$ \\
\hline
\end{tabular}

Specific storage is given in units of per meter $[1 / \mathrm{m}]$.

\section{Datum}

Vertical coordinate information is referenced to the National Geodetic Vertical Datum of 1929 (NGVD29).

Horizontal coordinate information is referenced to the North American Datum of 1927 (NAD27) and North American Datum of 1983 (NAD83).

Altitude, as used in this report, refers to distance above the vertical datum. 


\title{
Stochastic Modeling of a Lava-Flow Aquifer System
}

\author{
By C. Cronkite-Ratcliff and G.A. Phelps
}

\begin{abstract}
This report describes preliminary three-dimensional geostatistical modeling of a lava-flow aquifer system using a multiple-point geostatistical model. The purpose of this study is to provide a proof-of-concept for this modeling approach. An example of the method is demonstrated using a subset of borehole geologic data and aquifer test data from a portion of the Calico Hills Formation, a lava-flow aquifer system that partially underlies Pahute Mesa, Nevada. Groundwater movement in this aquifer system is assumed to be controlled by the spatial distribution of two geologic units - rhyolite lava flows and zeolitized tuffs. The configuration of subsurface lava flows and tuffs is largely unknown because of limited data. The spatial configuration of the lava flows and tuffs is modeled by using a multiple-point geostatistical simulation algorithm that generates a large number of alternative realizations, each honoring the available geologic data and drawn from a geologic conceptual model of the lava-flow aquifer system as represented by a training image. In order to demonstrate how results from the geostatistical model could be analyzed in terms of available hydrologic data, a numerical simulation of part of an aquifer test was applied to the realizations of the geostatistical model.
\end{abstract}

\section{Introduction}

Pahute Mesa is a topographic mesa located partially in the northwestern corner of the Nevada National Security Site (formerly the Nevada Test Site) in southern Nevada. Underground nuclear testing near Pahute Mesa between 1965 and 1992 introduced contaminants into the subsurface (Stoller-Navarro Joint Venture, 2004). Therefore, understanding the spatial distribution of geologic units that affect the pathways of groundwater flow is necessary for investigating these groundwater contamination issues. Developing three-dimensional (3D) models of the subsurface is one way to analyze the effect of geologic units and their hydraulic properties on the pathways of groundwater flow. This study demonstrates a specific method for developing a 3D geologic model of the subsurface for lava-flow aquifer systems using a multiple-point geostatistical model. Although the method presented in this study is demonstrated using data from Pahute Mesa, it has potential applications in other lava-flow aquifer systems, as well as in other geologic settings.

The eastern part of Pahute Mesa is occupied by the Silent Canyon Caldera Complex, a structural caldera complex filled with sequences of lava flows and tuffs from multiple Miocene volcanic eruptions, centered both within and in the general vicinity of the calderas (Slate and others, 2000). The region was subject to faulting during and subsequent-to the deposition of the volcanic rocks. Several prominent north-trending Miocene extensional faults post-date the volcanic rocks of the area and cut across the mesa. The West Greeley Fault has the greatest offset, with an offset of up to $150 \mathrm{~m}$ at the surface (McKee and others, 2001).

The Calico Hills Formation is a sequence of rhyolitic lava flows, ash-fall tuffs, ash-flow tuffs, and tuff breccias that erupted approximately 12.9 Ma from several locations across the Southwestern Nevada Volcanic Field (Sawyer and others, 1994; Slate and others, 2000). In the Pahute Mesa area, the Calico Hills Formation occurs in the subsurface and for the most part is seen only in drill holes. This 
study focuses on the Calico Hills Zeolitized Composite Unit (CHZCM), a hydrostratigraphic unit within the Calico Hills Formation defined by Bechtel Nevada (2002). The CHZCM consists of a sequence of rhyolite lava flows embedded in tuffs. Tuffs within the CHZCM are predominantly zeolitized and therefore relatively impermeable; groundwater movement within the CHZCM is thought to occur through interconnected fractures in the rhyolite lava flows (Blankennagel and Weir, 1973).

The spatial distribution of the lava flow and tuff units in the subsurface is uncertain. Although outcrop and drill hole data offer information at specific locations, these data alone are insufficient to map the connectivity and lateral extent of individual lava flows (Prothro and others, 2009). One strategy for geologic modeling under uncertainty is to generate many different interpretations of the subsurface through stochastic simulation. In this study, several such interpretations are generated using multiplepoint geostatistical simulation (Strebelle, 2002). Multiple-point simulation reproduces patterns from a training image that represents how physical properties (and in this case, geologic units) are distributed in space. The use of a training image provides a way to integrate geologic knowledge into quantitative models, particularly in geologic environments where the geology is understood conceptually but the position and distribution of geologic units are uncertain.

In this study, a 3D model of the lava-flow aquifer system within a single fault block of the CHZCM is developed by using a multiple-point simulation algorithm to generate many alternative realizations of the study region. These realizations describe different configurations of lava flows and tuffs based on the patterns described by a training image. The training image is built using unconditional object-based simulation that captures the spatial characteristics specific to a conceptual model for the distribution of lava flows and tuffs within the CHZCM. All realizations are consistent with available geologic data. In order to demonstrate how this geostatistical model could be analyzed in terms of hydrologic data, a numerical simulation of the U-20 WW aquifer test, conducted within the CHZCM between October 2008 and October 2009 (Garcia and others, 2011), is used to measure how well each realization matches the observed hydraulic behavior of the aquifer system. During the U-20 WW aquifer test, groundwater was extracted from well U-20 WW, and water levels were continuously monitored in the three observation wells ER-20-6 \#3, UE-20bh 1, and U-20 bg.

Garcia and others (2011) estimated drawdown in each of the observation wells of the U-20 WW aquifer test. Garcia and others (2011) identified a drawdown detection threshold of $0.03 \mathrm{~m}$, below which the estimated drawdown could not be distinguished from unexplained error. Garcia and others (2011) concluded that drawdown in response to pumping at well U-20 WW could be detected only at well UE$20 \mathrm{bh}$ 1, which is located $1.9 \mathrm{~km}$ from well U-20 WW and is separated from well U-20 WW by the West Greeley Fault. By contrast, drawdown could not be detected at well ER-20-6 \#3, which is located on the same side of the West Greeley Fault as well U-20 WW and is located $1.1 \mathrm{~km}$ from well U-20 WW. The results of the aquifer test suggest that the heterogeneity of lava flow and tuff units is an important factor in controlling groundwater flow in the CHZCM. For example, Garcia and others (2011) explain the lack of detectable drawdown at well ER-20-6 \#3 on the presence of low-conductivity tuff separating well ER-20-6 \#3 from well U-20 WW.

Garcia and others (2011) used numerical simulation of the U-20 WW aquifer test to estimate the hydraulic properties of the lava flow and tuff units in the vicinity of U-20 WW, and to analyze hydraulic connections across the West Greeley Fault. More recently, the U-20 WW aquifer test was simulated by Harp and others (2012). In contrast to the stochastic model described in this study, both Garcia and others (2011) and Harp and others (2012) used a deterministic approach to model the spatial configuration of the geologic features in the vicinity of the U-20 WW aquifer test. Both of these numerical models used data and simulated groundwater flow on both sides of the West Greeley Fault. Garcia and others (2011) separated the model domain into lava and tuff sections and estimated hydraulic conductivity for the lava and tuff units on each side of the West Greeley Fault. The model by Harp and others (2012) included five individual lava zones, four faults including the West Greeley Fault, a zone 
for tuff, and zones representing rocks outside of the Calico Hills Formation. Harp and others (2012) estimated different hydraulic conductivity values for each of the five individual lava zones.

In the numerical simulation of the U-20 WW aquifer test described in this study, the aquifer system is represented as a 3D distribution of two hydrofacies (lava flows and tuffs), each of which is assigned a constant bulk hydraulic conductivity. The numerical simulation is based partly on the modeling of the U-20 WW aquifer test by Garcia and others (2011). This aquifer test simulation demonstrates how specific configurations of lava flow and tuff units that are most consistent with the aquifer test data could be identified.

\section{Purpose and Scope}

This report describes preliminary 3D geostatistical modeling of a lava-flow aquifer system using a multiple-point geostatistical model. The purpose of this study is to provide a proof-of-concept for this modeling approach, using a portion of the Calico Hills Zeolitic Composite Unit (CHZCM), a hydrostratigraphic unit within the Calico Hills Formation underlying Pahute Mesa, Nevada, as an example. The geostatistical model consists of two hydrofacies (lava flows and tuffs), the properties of which are assumed to control groundwater flow in the aquifer system. In order to demonstrate how results from the geostatistical model could be analyzed in terms of available hydrologic data, a numerical simulation of part of the U-20 WW aquifer test was applied to the realizations of the geostatistical model.

This study is a work in progress, and the geostatistical model and aquifer test simulation described in this study are preliminary. Several aspects of the geostatistical model and aquifer test simulation could be improved, extended, or investigated in future work. The spatial extent of the geostatistical model is restricted to a single fault block between the Boxcar Fault and the West Greeley Fault. As a result, the simulation of the U-20 WW aquifer test considers only the part of the aquifer test that took place to the west of the West Greeley Fault, and results are analyzed only on the basis of observations at well ER-20-6 \#3. A complete simulation of the U-20 WW aquifer test within the CHZCM would require modeling lava and tuff units on both sides of the West Greeley Fault, as well as analyzing results from all observation wells, which is beyond the scope of this study. The aquifer test simulation was developed for demonstration purposes and is subject to several limitations. For example, the parameters used in the numerical model of the aquifer test have not been calibrated. An assumption was made at the beginning of the study that for demonstration purposes, the aquifer system would be modeled using two hydrofacies in approximately equal proportions, representing a highly permeable lava-flow hydrofacies and a relatively impermeable tuff hydrofacies. However, data from previous studies of Pahute Mesa provide evidence for alternative hydraulic conductivity distributions within the CHZCM. Some of these alternative models are described in the "Discussion" section.

\section{Geologic Modeling}

\section{Preparation of Geologic Data}

The study region is a 3D section of the CHZCM that ranges in thickness from 800 to 1,200 m. This section encompasses the full vertical extent of the CHZCM within a rectangular area that measures $2,800 \mathrm{~m}$ from east to west and 5,650 $\mathrm{m}$ from north to south. The study region is located partially within the saturated zone and is buried by approximately $600 \mathrm{~m}$ of unsaturated rock. The UTM coordinates (NAD83, zone 11) of its southwestern corner are 548,818.75 m Easting, 4,119,868.75 m Northing (37 $\left.13^{\prime} 26.57^{\prime \prime} \mathrm{N}, 116^{\circ} 26^{\prime} 58.95^{\prime \prime} \mathrm{W}\right)$. The base and top of the study region is bounded by the base and top of the CHZCM, as defined in the Phase II 3D geologic model of Pahute Mesa (provided by National 
Security Technologies, LLC, written commun., December, 2011). This study area is bounded roughly by the Boxcar Fault on the west and by the West Greeley Fault on the east (fig. 1).

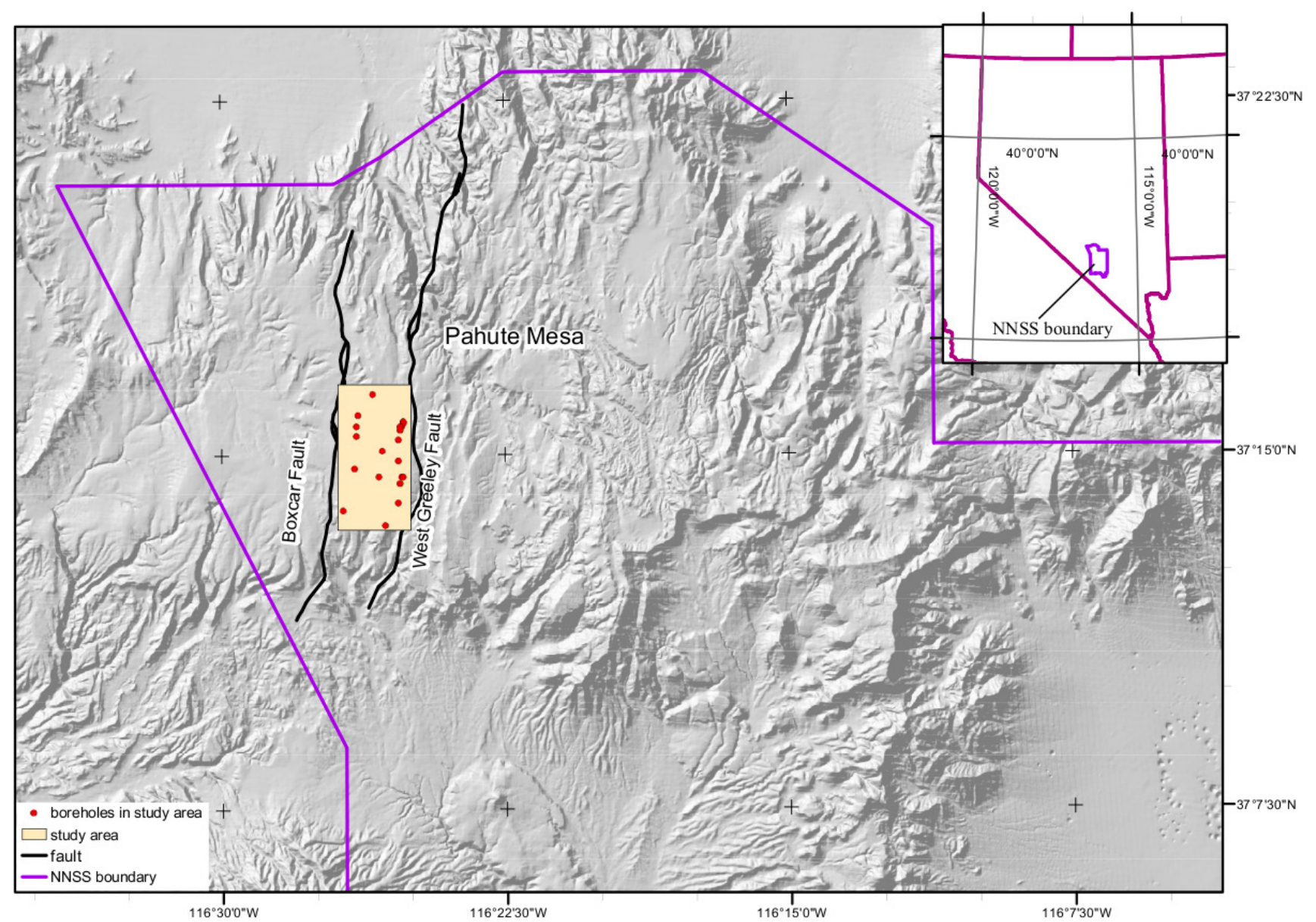

Figure 1. Map showing location of the study area and boreholes in Pahute Mesa, Nevada, located within the Nevada National Security Site (NNSS); horizontal coordinates are referenced to NAD83. 
Within the study area, rocks are classified into two hydrofacies: (1) a permeable lava-flow aquifer hydrofacies, representing potentially connected lava flows; and (2) a surrounding, less permeable background hydrofacies, representing the zeolitized tuffs. The two hydrofacies correspond to the two dominant hydrogeologic units (HGUs) within the CHZCM in the study area, the lava-flow aquifer (LFA) and the tuff confining unit (TCU), respectively (Prothro and others, 2009). These hydrofacies are subsequently referred to as the "lava-flow hydrofacies" and the "tuff hydrofacies".

Geologic data from 21 boreholes that penetrate the CHZCM within the study region (fig. 2) are used to condition the geostatistical simulations. Only the sections of each borehole that intersect the CHZCM are used. Only one borehole, UE-20h, fully penetrates the CHZCM. All other boreholes within the study region reach their maximum depth within the CHZCM.

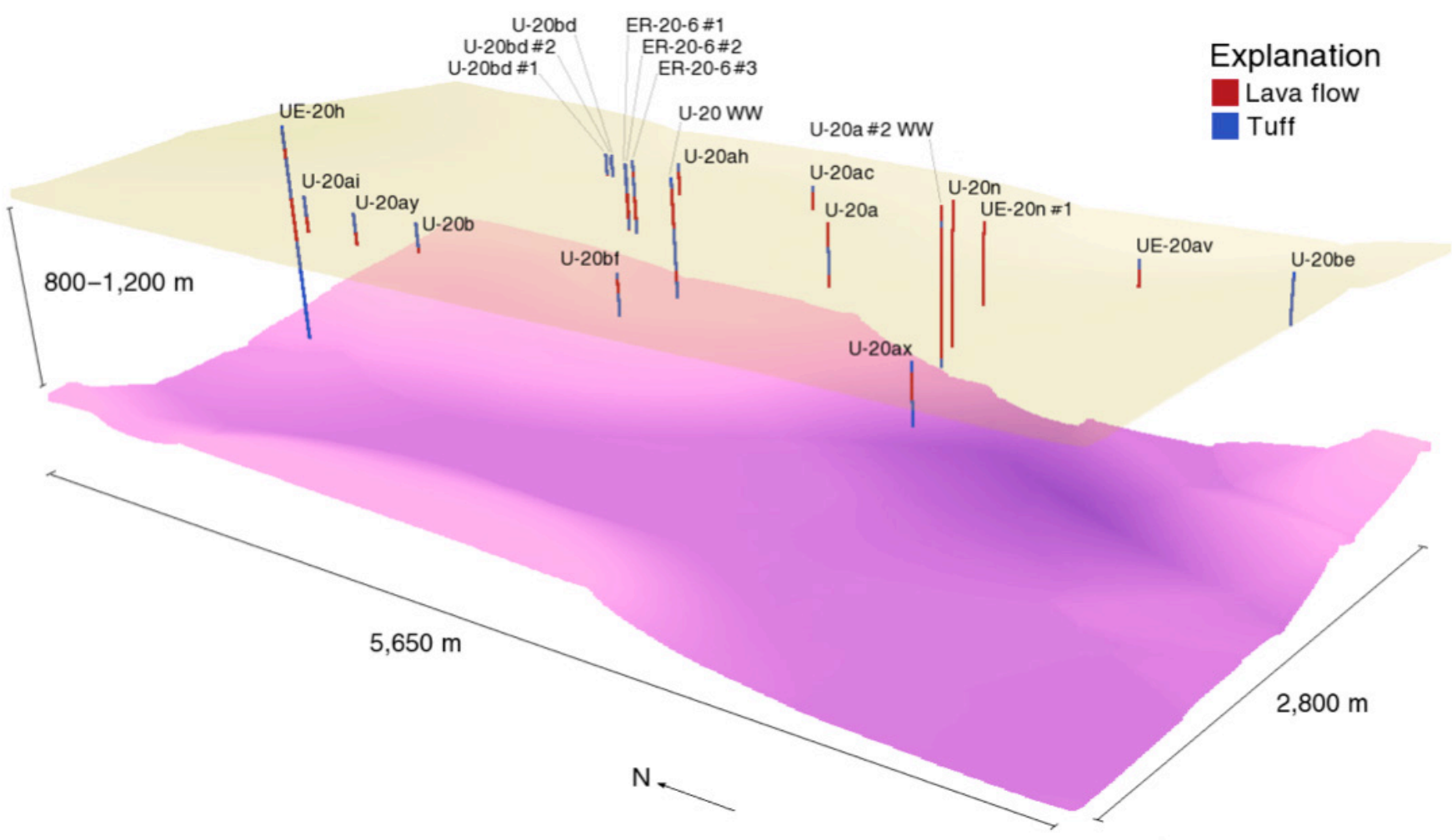

Figure 2. Three-dimensional image of the study area, showing the full vertical extent of the Calico Hills Zeolitic Composite Unit and geologic data from the 21 boreholes that penetrate the Calico Hills Zeolitic Composite Unit within the study region.

The borehole geologic data (Bechtel Nevada, 2002) have been classified into HGUs according to lithology, degree of fracturing, and post-depositional alteration (Prothro and others, 2009). About 96 percent of the data, by length, are classified as either LFA or TCU, and therefore are already consistent with the two-hydrofacies framework. The remaining 4 percent are initially classified as either intrusive confining unit (ICU), vitric tuff aquifer (VTA), or welded tuff aquifer (WTA). In order to remain consistent with the two-hydrofacies framework, these rocks were grouped with either the lava-flow or tuff hydrofacies by L. Prothro of National Security Technologies, LLC (written commun., January, 2012). 


\section{Training Image}

A training image (Strebelle, 2000) is a collection of patterns that describe the spatial distribution of geologic units in the subsurface. A training image can be constructed from various sources that provide these patterns, such as surface outcrops, geologic maps, or satellite images. However, the information provided by these sources is mostly restricted to two dimensions. In general, 3D multiplepoint geostatistical simulation requires a 3D training image, which generally is a 3D gridded volume with properties known at all locations. In this case, the training image needs to describe the 3D configurations of lava flows and tuffs. Therefore, a training image was built using an object-based algorithm that generates a field of randomly positioned 3D parametric shapes (Maharaja, 2008).

In the training image, rhyolite lava flows are represented as a series of upper-half ellipsoids. The interaction of these upper-half ellipsoids could represent a range of shapes seen in rhyolite lava flows (Cas and Wright, 1987). The upper-half ellipsoids could potentially represent individual lava domes, but they also may overlap with one another to form shapes representing larger elongated flows. In order to simulate the variability in the horizontal and vertical extent of individual lava flows, these upper-half ellipsoids were generated with stochastically generated dimensions. For rhyolite flows with a circular plan, data compiled by Walker (1973) shows a maximum diameter between 4,000 and 5,000 m, and a maximum thickness between 500 and $600 \mathrm{~m}$. Walker (1973) also gives a median length of $1.1 \mathrm{~km}$ and an average thickness of $100 \mathrm{~m}$ for rhyolite lava flows.

The dimensions of the upper-half ellipsoids in the training image were drawn from triangular probability distributions with assumed parameters. These triangular probability distributions are not the same as the distributions described by Walker (1973), but share some similar characteristics: the distribution of horizontal diameter ranged from 500 to $5,000 \mathrm{~m}$, with a mode of $1,100 \mathrm{~m}$, and the distribution of vertical thickness ranged from 25 to $500 \mathrm{~m}$, with a mode of $100 \mathrm{~m}$.

The training image is 250 grid cells in each horizontal dimension and 50 grid cells in height (fig. 3). Cells were assumed to measure $25 \mathrm{~m}$ in each dimension, the same dimensions as the geostatistical model. The lava-flow hydrofacies comprises the union of these upper-half ellipsoids, and the tuff hydrofacies fills the surrounding volume. The lava-flow hydrofacies and the tuff hydrofacies each comprise about 50 percent of the training image volume. These proportions are consistent with the estimate by Prothro and Drellack (1997) that the average proportion of LFA within the CHZCM also is about 50 percent. These proportions also agree with the drill-hole data, in which 54 percent of the data, by length, is classified as the lava-flow hydrofacies, and 46 percent as the tuff hydrofacies. 

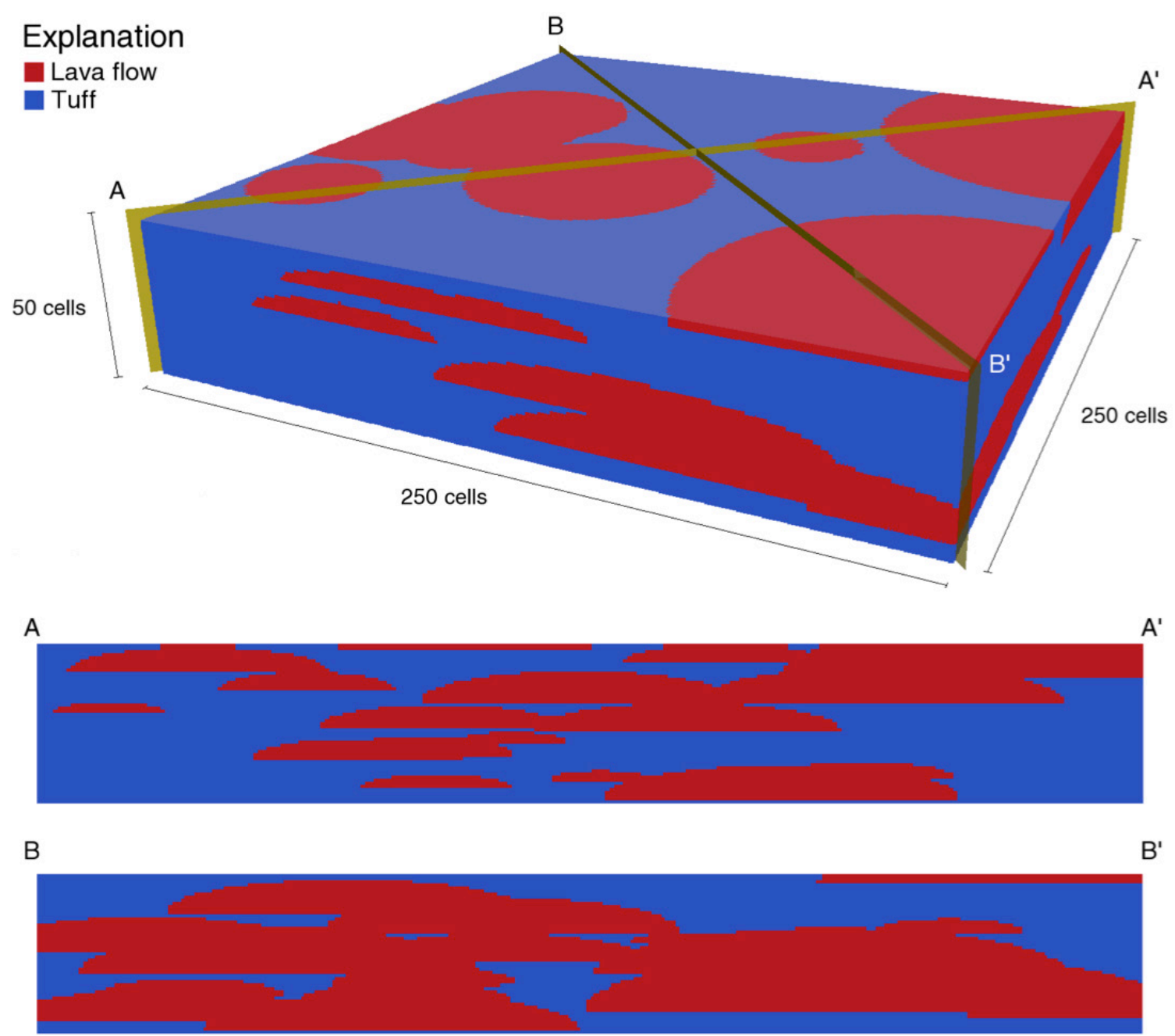

Figure 3. Three-dimensional image of the training image, showing two-dimensional cross-sections from two slices along the vertical planes A-A' and B-B'.

\section{Realizations}

One thousand realizations were generated using multiple-point geostatistical simulation, each representing a unique distribution of the hydrofacies within the study area and honoring all borehole geologic data. Each realization was generated on a 3D regular grid measuring 112 cells from east to west, 226 cells from north to south, and 48 cells in vertical thickness, with cells measuring $25 \mathrm{~m}$ in each dimension. Four examples of the realizations are shown in figure 4. 


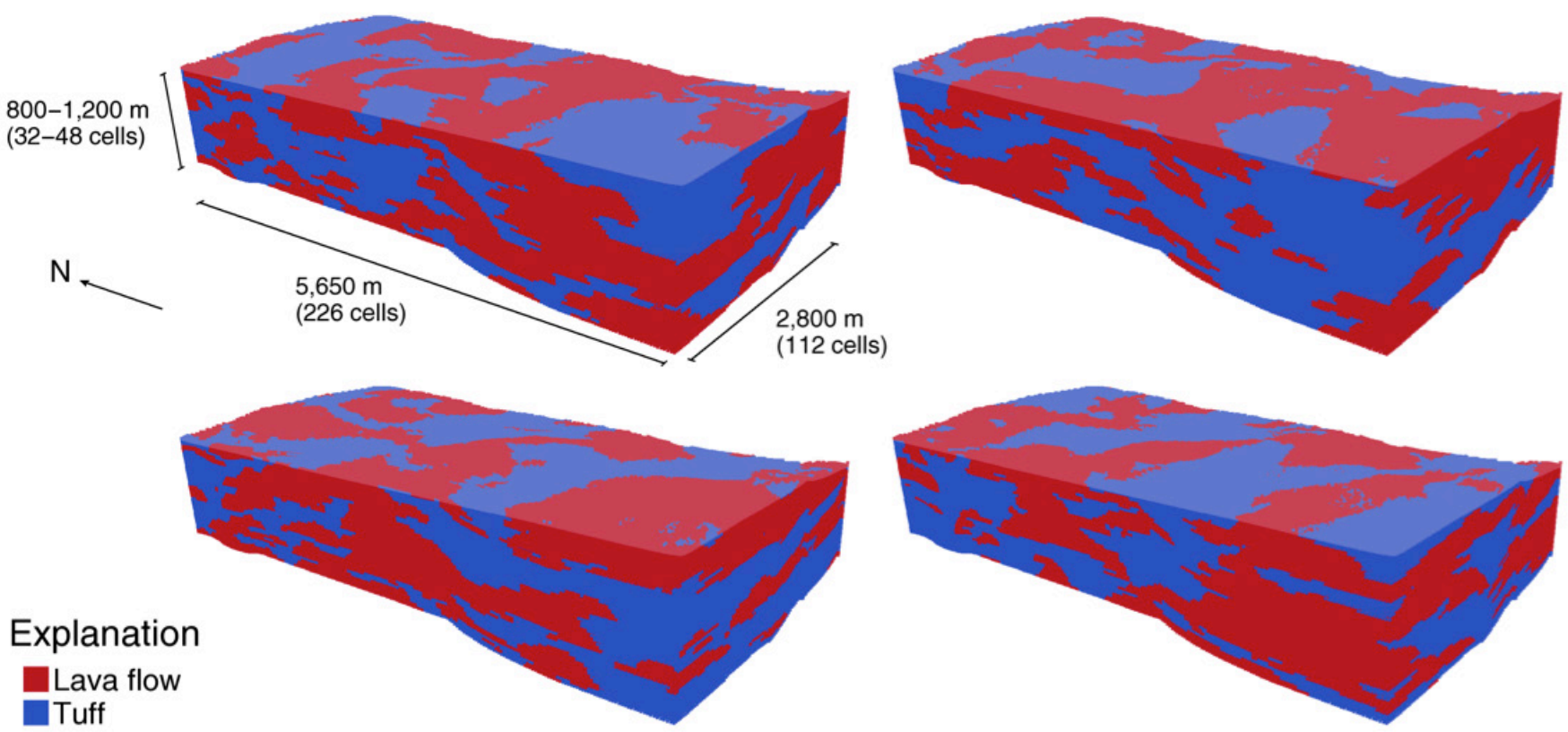

Figure 4. Three-dimensional images of 4 of the 1,000 realizations generated using multiple-point geostatistical simulation.

Each realization is generated by using the Single Normal Equation Simulation (SNESIM) algorithm developed by Strebelle (2002). This algorithm first obtains the patterns in the training image that fit within a template of a specific size and shape. The algorithm then stores them in a search tree, and assigns them a probability of occurrence based on their frequency in the training image. The probabilities associated with each of the patterns in the search tree are then used for simulating hydrofacies in the study region. At the beginning of each simulation, the hydrofacies are assigned only in the cells intersected by the borehole data. The algorithm then visits each cell in the grid in a random sequence, and assigns a hydrofacies to each cell based on the probabilities stored in the search tree and the hydrofacies that have already been assigned at nearby locations. As the simulation progresses, more conditioning data are available. The resulting realization exhibits patterns similar to those in the training image. The proportions of each hydrofacies observed in the borehole geologic data are reproduced approximately in the realizations. Out of the 1,000 realizations, the proportion of lava-flow hydrofacies ranged from 41 to 65 percent, with a mean of 54 percent. Ninety-five percent of the realizations had proportions of lava-flow hydrofacies between 47 and 61 percent.

In order to demonstrate how non-stationary features such as local topography might be incorporated into this geostatistical model, the shape of the lava flows was assumed to conform to the lower boundary of the study region, an irregular topographic surface. To accomplish this task, the drill hole data were shifted vertically by the distance necessary to correspond to a flattened basal topographic surface. The geostatistical simulation was then performed on a rectangular grid with a slightly larger vertical range than the study region. The resulting realization was again deformed by shifting cells vertically to match the original basal topographic surface. This modification ensured that the shape of the lava flows conformed to the slope of the study region's lower boundary, and that the lower boundary of the realization grid was consistent with that of the study region. The vertical extent of the grid was made consistent with the upper boundary of the study region by removing cells from the grid with coordinates above the upper boundary of the study region. 


\section{Aquifer Test Simulation}

In order to demonstrate how specific realizations generated by the geostastical model could be compared with hydrologic data, a portion of the U-20 WW aquifer test was simulated on each realization using MODFLOW-2005 (Harbaugh, 2005). Only the part of the aquifer test that was located within the study region, to the west of the West Greeley Fault, was simulated. The results of the simulation therefore can only be compared to data from the single observation well ER-20-6 \#3. Because wells U-20 WW and ER-20-6 \#3 are open to lava flows, the shape and extent of the lava flows penetrated by these two wells can be modeled. The numerical model of the aquifer test is preliminary, and the parameters used in the model have not been calibrated.

The area of interest for the MODFLOW-2005 simulations was restricted to a rectangular subregion large enough to contain the pumping well U-20 WW and the observation well ER-20-6 \#3. The horizontal extent of this subregion consists of the interval between the cells containing wells U-20 WW and ER-20-6 \#3, with an additional 350-375 m buffer on each side (figs. 5 and 6). This subregion measures 1,475 m east-west and 1,675 m north-south, and encompasses the full vertical extent of the study region within these horizontal boundaries.

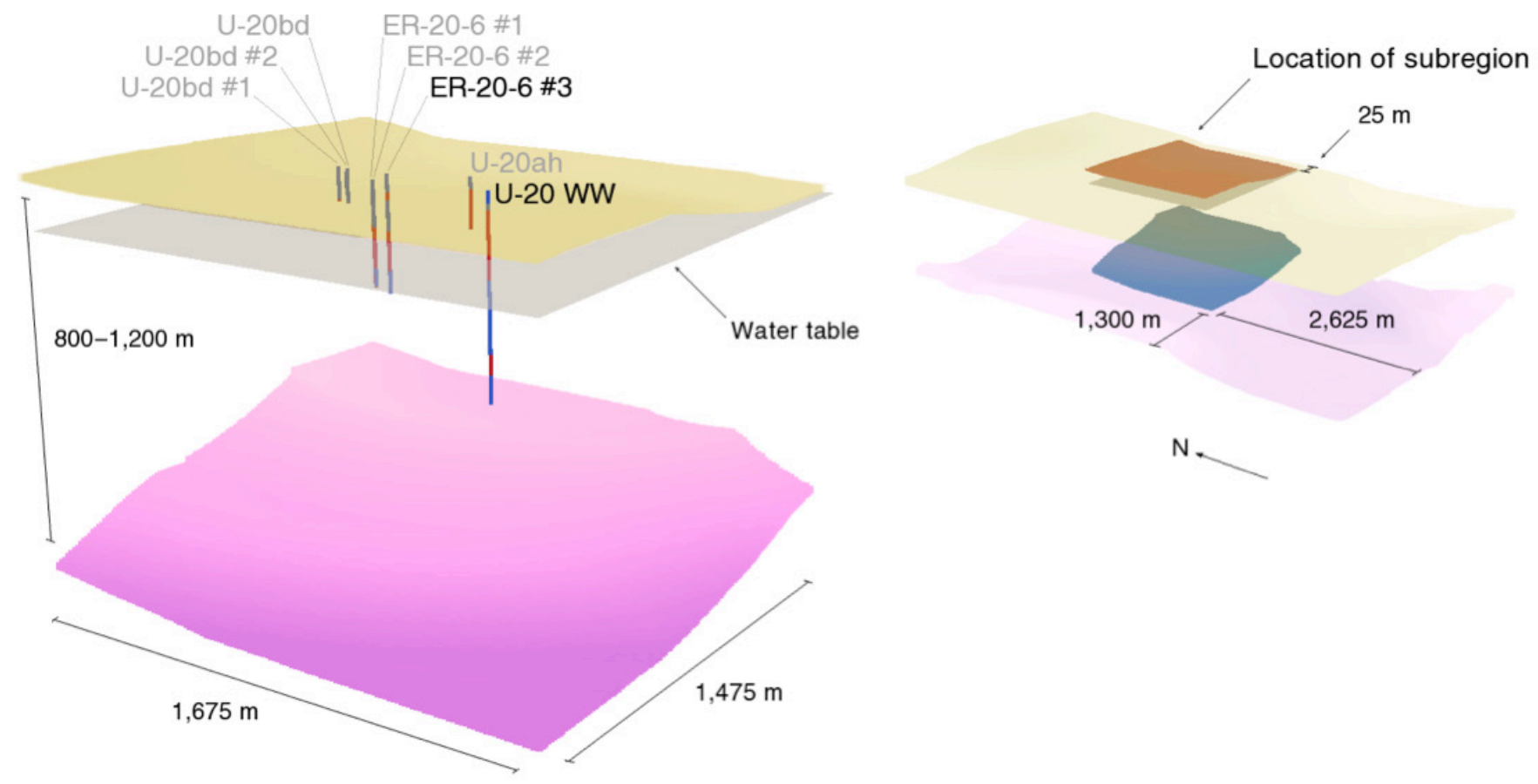

Figure 5. Three-dimensional image of the subregion used for simulation of the aquifer test, showing the location of the subregion within the study region, the pumping well (U-20 WW), and the observation well (ER-20-6 \#3). 

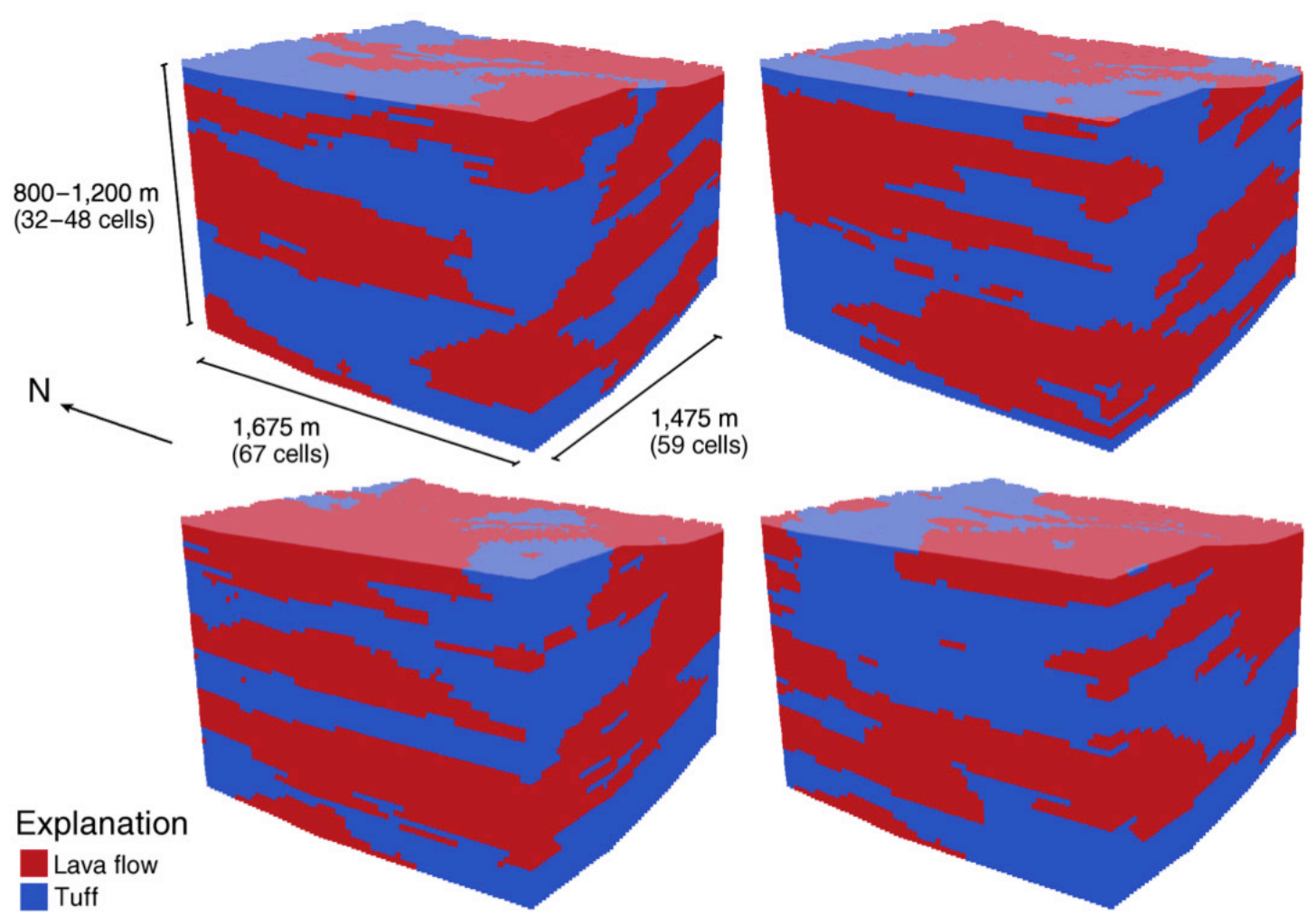

Figure 6. Three-dimensional images of four realizations generated using multiple-point geostatistical simulation, showing cells located only within the subregion.

The MODFLOW-2005 simulation grid consists of an "inner grid" within this subregion (figs. 5 and 6) and an "outer grid" extending beyond the subregion. The entire grid has a total of 135 rows and 143 columns, with the inner grid consisting of the central 67 rows and 75 columns (fig. 7). The inner grid has a discretization of $25 \mathrm{~m}$ on a side, except for the area near well U-20 WW. Surrounding well U$20 \mathrm{WW}$ is a refined mesh of nine rows and nine columns with horizontal dimensions increasing away from the well and ranging from 0.06 to $11.12 \mathrm{~m}$. In the outer grid, row and column widths increase incrementally outward by a factor of 1.25 from the inner grid dimensions of $25 \mathrm{~m}$. 


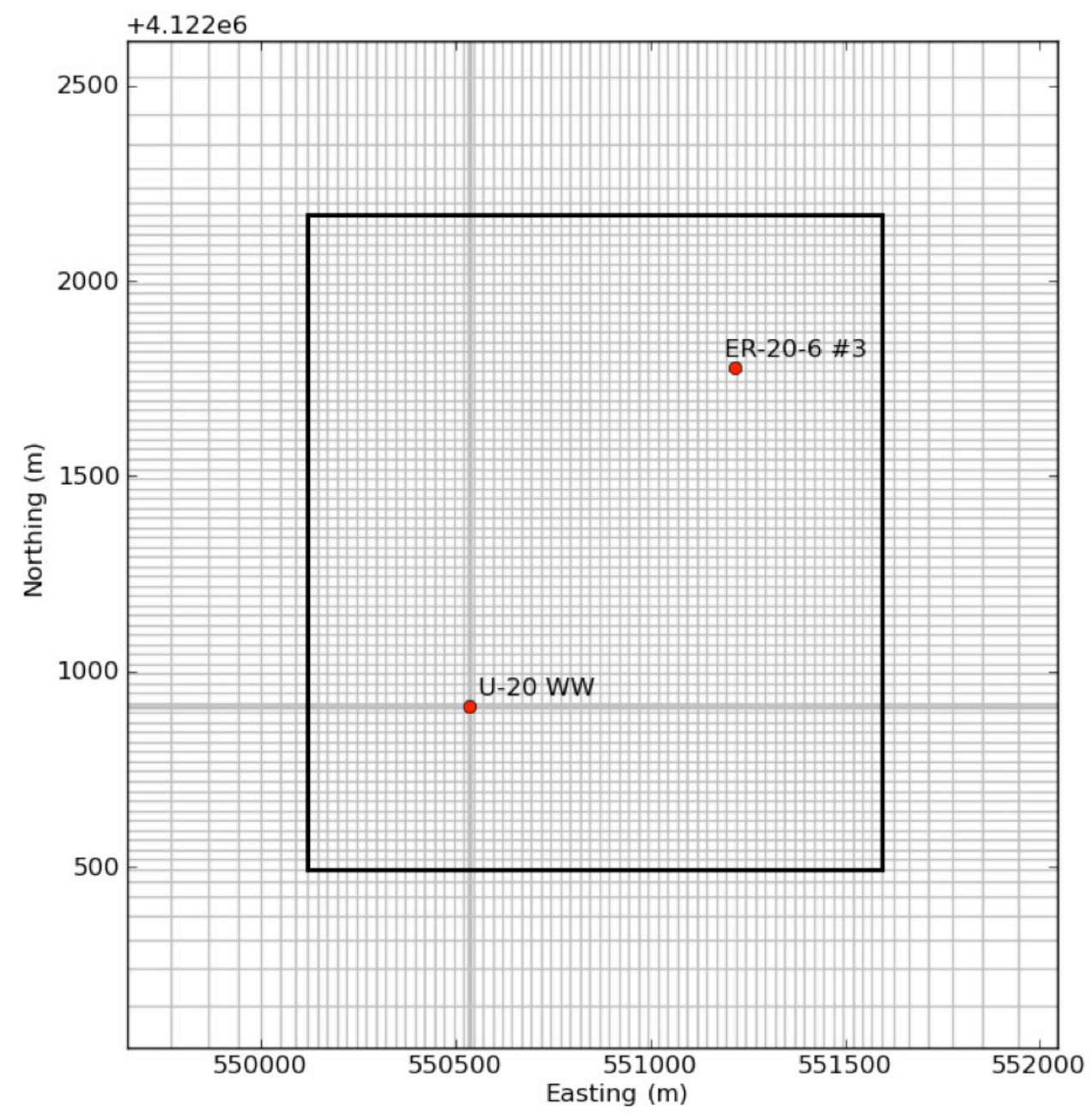

Figure 7. Discretization of the MODFLOW grid used for groundwater flow simulation, showing the area corresponding to the subregion of the geostatistical model (outlined with the thick line).

The horizontal extent of the entire grid measures approximately $500 \mathrm{~km}$ east-west and northsouth. Similar to Garcia and others (2011), the horizontal extent of the simulation grid is much larger than the inner grid in order to accommodate no-flow boundary conditions while approximating an aquifer with infinite lateral extent. The grid has 48 layers, with each layer measuring $25 \mathrm{~m}$ in height, matching the vertical dimension of the geostatistical modeling grid. The altitude of the lower boundary of the inner grid was assumed to be the lower boundary of the CHZCM. Outside the inner grid, the altitude of the lower boundary was assigned from the altitude of the lower boundary at the nearest inner grid cell.

Similar to Garcia and others (2011), groundwater flow was assumed to be confined, with the upper boundary defined at a constant altitude of 1,350 m (NGVD29) to represent the approximate altitude of the water table in well U-20 WW (U.S. Geological Survey, 2014). Conditions of no flow were assumed at all model boundaries.

Pumping was specified at a single cell where lava flows intersect the production zone of well U$20 \mathrm{WW}$. Observations were made at a single cell corresponding to a lava flow intersection within the perforated zone of well ER-20-6 \#3. Because well U-20 WW is an open-hole completion within the CHZCM, vertical hydraulic conductivity is set to $10^{5} \mathrm{~m} / \mathrm{d}$ in the vertical stack of cells that represent the borehole. Because of the high vertical hydraulic conductivity, pumped water could be drawn from any 
depth within this column. Specific storage also was set to zero in all cells along the vertical stack representing the borehole. The only exception is a single cell above the perforated zone where the specific storage was set to 1.7 per meter, which accounts for the release of water from wellbore storage.

For each individual aquifer test simulation, the hydraulic conductivity within the inner grid was drawn directly from the hydrofacies distribution of the corresponding realization using rock hydraulic properties from Garcia and others (2011) (table 1). Cells outside the inner grid were assigned the arithmetic mean of the hydraulic conductivity of the two hydrofacies $(0.75 \mathrm{~m} / \mathrm{d})$. The arithmetic mean was used in this case because it is assumed that flow through connected lava flows results in a relatively high effective hydraulic conductivity.

The aquifer test was simulated with six stress periods that included three pumping and recovery cycles each (table 2), similar to Garcia and others (2011).

Table 1. Hydraulic properties used in the aquifer test simulation.

\begin{tabular}{ll}
\hline \multicolumn{1}{c}{ Property } & \multicolumn{1}{c}{ Value } \\
\hline Hydraulic conductivity of lava-flow hydrofacies & 1.5 meters per day \\
Hydraulic conductivity of tuff hydrofacies & $3 \times 10^{-4}$ meters per day \\
Specific storage & $6.9 \times 10^{-6}$ per meter \\
Vertical to horizontal anisotropy & 1.0 (no anisotropy) \\
\hline
\end{tabular}

Table 2. Stress periods and status of pumping well in the aquifer test simulation.

\begin{tabular}{ccl}
\hline Stress period & Length, in days & Status of pumping or recovery in well U-20 WW \\
\hline 1 & 56.1 & Pumping at 209 cubic meters per day \\
2 & 173.9 & Recovery \\
3 & 28.1 & Pumping at 79 cubic meters per day \\
4 & 8.7 & Recovery \\
5 & 18.2 & Pumping at 171 cubic meters per day \\
6 & 156.4 & Recovery \\
\hline
\end{tabular}

\section{Analysis of Aquifer Test Simulation}

For each realization, the time series of hydraulic head simulated at well ER-20-6 \#3 was compared to the drawdown detection threshold of $0.03 \mathrm{~m}$ estimated by Garcia and others (2011). All realizations where simulated drawdown in well ER-20-6 \#3 did not exceed 0.03 m between April 1, 2009 and October 1, 2009, were identified as realizations that are most consistent with the aquifer test data. The simulated drawdown was less than $0.03 \mathrm{~m}$ for 106 of the 1,000 realizations during this period. The time series of simulated drawdown in well ER-20-6 \#3 are shown in figure 8.

A preliminary analysis of connectivity between wells U-20 WW and ER-20-6 \#3 was conducted on each realization by using a breadth-first search algorithm (Cormen and others, 2009) to find a connected path of lava-flow grid cells between the pumping cell and the observation cell. Both of these 
cells are located in lava-flow hydrofacies in all 1,000 realizations. If the pumping and observation nodes are not connected by a path of adjacent cells with lava-flow hydrofacies, then they are separated by at least one cell with tuff hydrofacies. Two different cubic cells with lava-flow hydrofacies were considered to be adjacent if they shared any face, edge, or corner. Of the 972 realizations where the pumping and observation zones were connected by a path of lava-flow hydrofacies, the simulated drawdown was less than $0.03 \mathrm{~m}$ in 80 realizations (fig. 8a). Of the 28 realizations where the pumping and observation zones were not connected by a path of lava-flow hydrofacies, the simulated drawdown was less than $0.03 \mathrm{~m}$ in 26 realizations; of the remaining two realizations, the maximum drawdown simulated between April 1, 2009 and October 1, 2009, was 0.04 (fig. 8b). 
a)

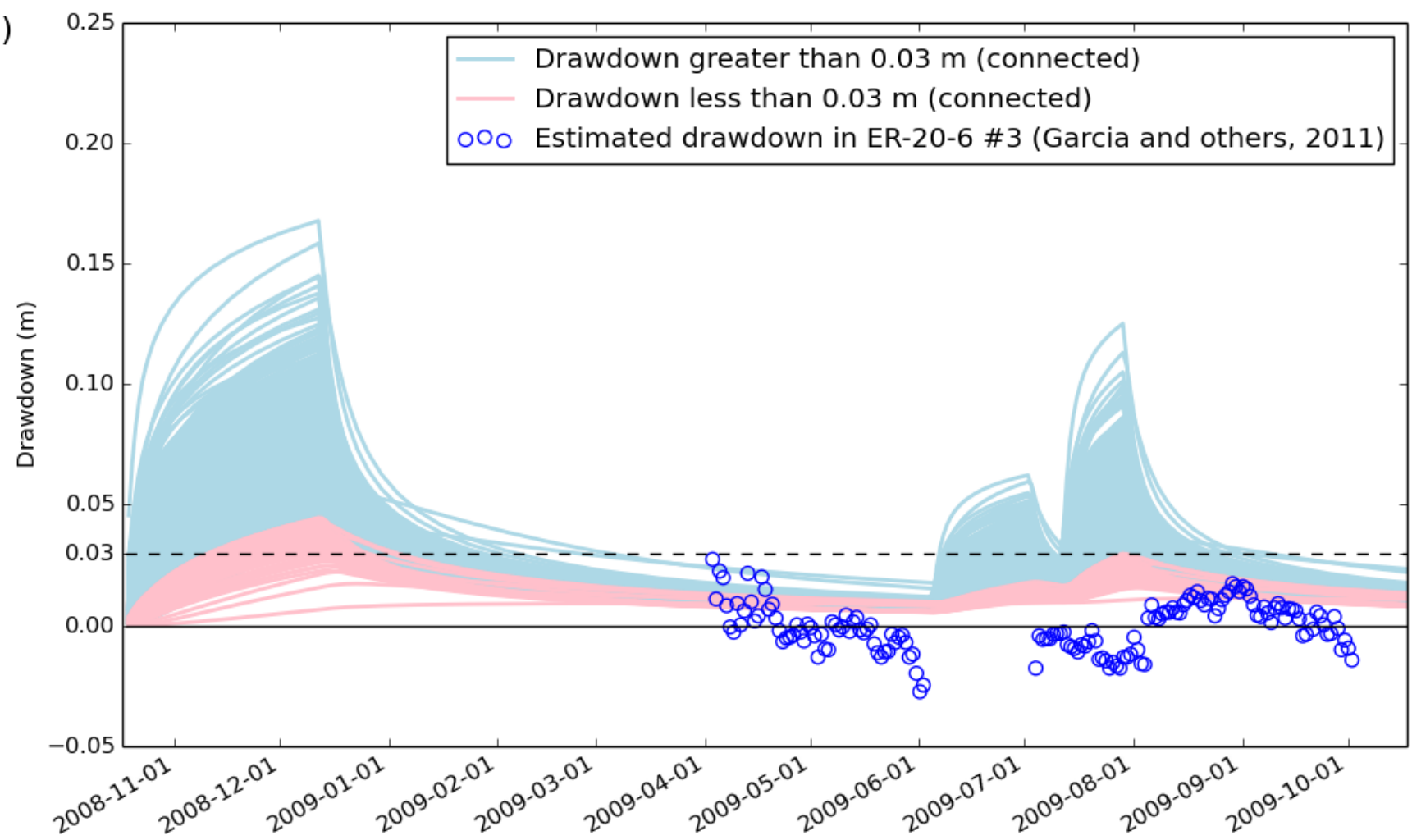

b)

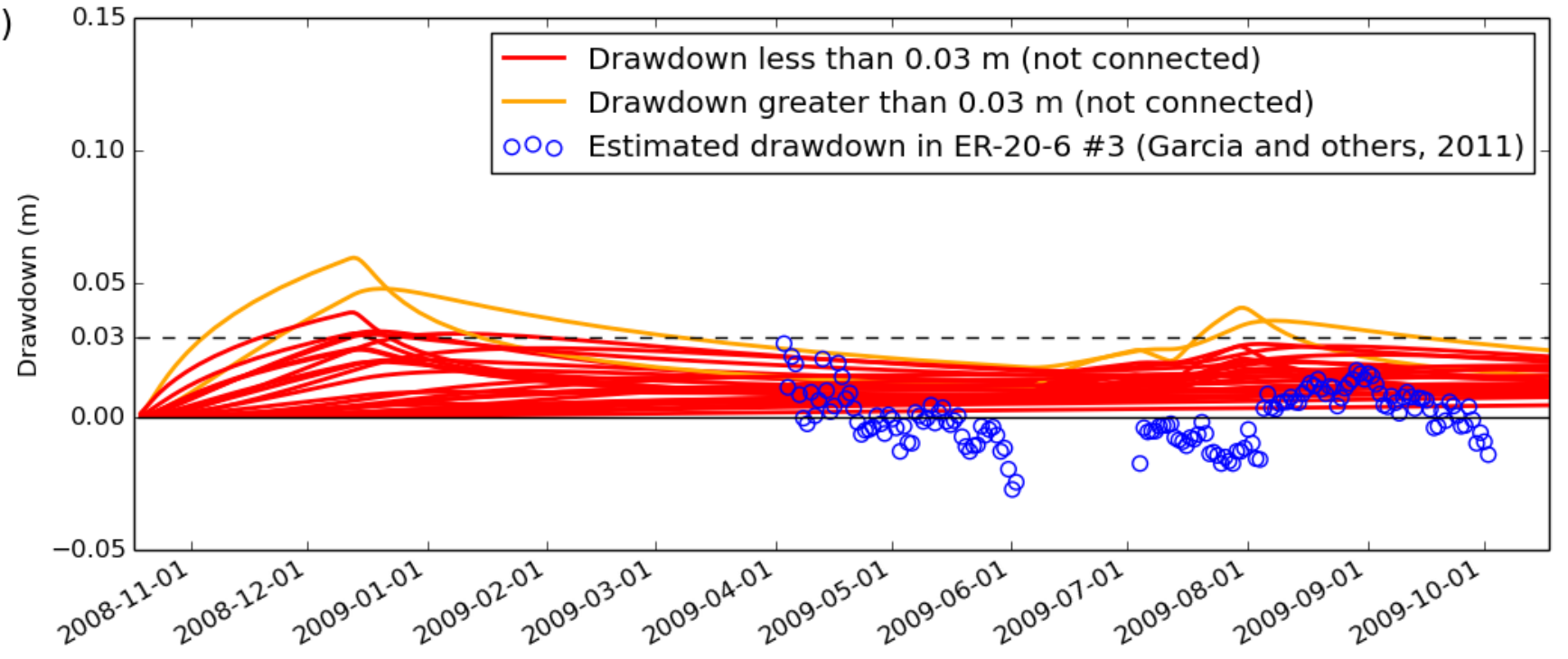

Figure 8. Graphs showing simulated drawdown and estimated drawdown by Garcia and others (2011) in well ER20-6 \#3; (a) shows realizations where the pumping zone in well U-20 WW is connected to the observation zone in well ER-20-6 \#3 by a path of adjacent grid cells with lava flow hydrofacies; (b) shows realizations where these two zones are not connected.

\section{Discussion}

In most of the realizations where the pumping and observation wells were separated by a section of tuff, the simulated drawdown in well ER-20-6 \#3 was less than $0.03 \mathrm{~m}$. This result supports the assumption of Garcia and others (2011) that wells U-20 WW and ER-20-6 \#3 are separated by tuff. 
However, the pumping and observation wells were connected in most of the realizations where the simulated drawdown was less than $0.03 \mathrm{~m}$. This result suggests that the drawdown in well ER-20-6 \#3 could be explained by factors other than the connectivity of the lava flows intersecting the pumping and observation wells. These factors could include the size, shape, and relative location of lava flows intersecting either the pumping or observation well, and are areas that could be investigated in future work. Additionally, in two of the realizations where the pumping and observation wells were separated by at least one cell of tuff, the simulated drawdown in well ER-20-6 \#3 was greater than $0.03 \mathrm{~m}$. Although a more extensive analysis of the relationship between connectivity and drawdown in well ER20-6 \#3 is outside the scope of this study, it could be a topic for investigation in future work.

About 10 percent of the 1,000 realizations yielded results that were consistent with the data from the observation well ER-20-6 \#3. This result raises the question of whether a different conceptual model could improve the number of realizations that are consistent with the aquifer test data. Developing a different conceptual model would involve modifying the way that geologic units are represented in the geostatistical model and how the values of their hydraulic properties (such as hydraulic conductivity and specific storage) are assigned.

The fact that the pumping and observation nodes are connected by lava-flow hydrofacies in more than 97 percent of the realizations suggests that some aspects of the training image may not be realistic. In particular, the lava-flow hydrofacies may be connected with a much greater frequency in the training image than can be supported by the results of the aquifer test. One possible alternative model for a training image would consider (1) reducing the proportion of the rhyolite lava flows in the training image, (2) decreasing the size of the lava flows, and/or (3) reducing the degree of overlap between individual lava flows. Implementing an alternative model as described above could yield a larger number of realizations where the pumping and observation nodes are not connected by the lava-flow hydrofacies. A larger number of such realizations could result in a range of different configurations and a range of widths of separating tuff. The results of such a model would allow for a more extensive analysis of connectivity, and lack thereof, between the wells in the aquifer test.

In this study, the lava-flow hydrofacies was assigned a homogeneous and relatively high hydraulic conductivity, based on the approach of Garcia and others (2011). However, previous studies of groundwater flow in Pahute Mesa have suggested that the rhyolite lava flows have a wider range of hydraulic conductivity than considered in this study. For example, Blankennagel and Weir (1973, p. B8) state that "some of the rhyolitic lavas are relatively impermeable." Laczniak and others (1996) also state that groundwater flow is impeded by non-fractured sections within the rhyolite lava flows themselves. An alternative model might therefore consider a range of hydraulic conductivity within the lava-flow hydrofacies. For example, in Pawloski and others (2001), the rhyolitic lavas are modeled with four different hydrofacies, each of which is assigned a different intrinsic permeability. Pawloski and others examined data from hydraulic tests in Pahute Mesa and concluded that less than one-half of the lava flows have high hydraulic conductivity on the same order of magnitude as in this study. By contrast, the hydraulic conductivity of the remaining parts of the lava flows can be as low as the hydraulic conductivity assigned to the tuff in this study. Therefore, another alternative model could consist of connected lava flows with a range of hydraulic conductivity; only a small proportion of the lava flows would have hydraulic conductivity as high as considered in this study.

Harp and others (2012) provide an example of a model where lava flows have a range of hydraulic conductivity. Harp and others estimated different values of hydraulic conductivity for five individual lava zones in order to simulate the drawdown observed during the aquifer test. The hydraulic conductivity in the two lava zones intersecting well U-20 WW were estimated at 0.1 to $0.3 \mathrm{~m} / \mathrm{d}$. Harp and others also estimated a high hydraulic conductivity $(>90 \mathrm{~m} / \mathrm{d})$ in the lava zone intersecting well ER20-6 \#3. Harp and others (2012) state that the presence of such a high conductivity zone around well 
ER-20-6 \#3 is another possible explanation for the lack of drawdown observed in well ER-20-6 \#3 during the aquifer test.

Both the geostatistical model and aquifer test simulation are preliminary and could benefit from further work in several additional ways. The geostatistical model and the aquifer test simulation could be extended to describe the aquifer system on both sides of the West Greeley Fault. Such an extended model would include additional borehole geologic data as well as additional aquifer test data that could be used to constrain the results. Another area for future work would be an investigation of whether the results of the aquifer test could be better explained by different parameter values, obtained either through model calibration or from additional data. Preliminary tests suggest that the results of the aquifer test simulation are sensitive to the hydraulic conductivity value assigned in the region outside the inner grid. The effect of this parameter on the results is another topic for further investigation.

The simulation of the U-20 WW aquifer test considers only the part of the aquifer test that took place to the west of the West Greeley Fault, and results are analyzed only on the basis of observations at well ER-20-6 \#3. The simulated hydrologic conditions in other parts of the modeling domain therefore may not be realistic. However, more data and analysis is needed to determine how to appropriately select these realizations. A more extensive analysis of simulated hydrologic conditions in other parts of the modeling domain should be another area for further investigation.

\section{Conclusions}

One of the challenges of groundwater modeling is to produce a model that is consistent with data of different types. This task often includes constructing models that are consistent with geologic concepts and quantitative data obtained from borehole logs and aquifer tests. The multiple-point geostatistical approach provides a way to accomplish this task. This approach uses a training image to incorporate the spatial characteristics of lava flows and tuffs into the model. These spatial characteristics are reproduced in the realizations generated by the multiple-point geostatistical simulation, each of which is consistent with the borehole geologic data. This study also demonstrates how the realizations generated by stochastic geostatistical modeling can be incorporated into numerical groundwater flow simulation. Analyzing results of the aquifer test simulation can provide insight into the relationship between geologic heterogeneity and the behavior of the aquifer system. It also allows the identification of ways to improve the geostatistical model and the aquifer test simulation when implementing this approach in geologic and hydrologic investigations.

\section{Acknowledgments}

We would like to thank the reviewers for their time, effort and guidance. With their help the report was much improved. This report was made possible by funding from the U.S. Department of Energy under Interagency Agreement DE-NA0001654 with the Department of Energy, National Nuclear Security Administration. 


\section{References Cited}

Bechtel Nevada, 2002, A hydrostratigraphic model and alternatives for the groundwater flow and contaminant transport model of corrective action units 101 and 102-Central and western Pahute Mesa, Nye County, Nevada: U.S. Department of Energy Report DOE/NV/11718-706, 383 p.

Blankennagel, R.K., and Weir, J.E., Jr., 1973, Geohydrology of the eastern part of Pahute Mesa, Nevada Test Site, Nye County, Nevada: U.S. Geological Survey Professional Paper 712-B, 35 p.

Cas, R.A.F., and Wright, C., 1987, Volcanic successions: London, Chapman \& Hall, 528 p.

Cormen, T.H., Leierson, C.E., Rivest, R.L., and Stein, C., 2009, Introduction to algorithms: Cambridge, Mass., MIT Press, 1,292 p.

Garcia, C.A., Fenelon, J.M., Halford, K.J., Reiner, S.R., and Laczniak, R.J., 2011, Assessing hydraulic connections across a complex sequence of volcanic rocks-Analysis of U-20 WW multiple-well aquifer test, Pahute Mesa, Nevada National Security Site, Nevada: U.S. Geological Survey Scientific Investigations Report 2011-5173, 24 p.

Harbaugh, A.W., 2005, MODFLOW-2005, the U.S. Geological Survey modular ground-water modelThe ground-water flow process: U.S. Geological Survey Techniques and Methods 6-A16, variously paginated.

Harp, D.R., Kwicklis, E.M., Wolfsberg, A.V., Moulton, J.D., Lipnikov, K.N., Gable, C.W., Becker, N.M., Berndt, M., and Vesselinov, V.V., 2012, ASCEM pumping test capabilities-Benchmarking and demonstration for UGTA at U-20 WW: Los Alamos National Laboratory report LA-UR-1226614, 32 p.

Laczniak, R.J., Cole, J.C., Sawyer, D.A., and Trudeau, D.A., 1996, Summary of hydrogeologic controls on ground-water flow at the Nevada Test Site, Nye County, Nevada: U.S. Geological Survey WaterResources Investigations Report 96-4109, http://pubs.usgs.gov/wri/wri964109/.

Maharaja, Amisha, 2008, TiGenerator-Object-based training image generator: Computers and Geosciences, v. 34, no. 12, p. 1,753-1,761.

McKee, E.H., Phelps, G.A., and Mankinen, E.A., 2001, The Silent Canyon Caldera-A threedimensional model as part of Pahute Mesa-Oasis Valley, Nevada, hydrogeologic model: U.S. Geological Survey Open-File Report 01-297, 21 p.

Pawloski, G.P., Tompson, A.F.B., and Carle, S.F., eds., 2001, Evaluation of the hydrologic source term from underground nuclear tests on Pahute Mesa at the Nevada Test Site-The CHESHIRE Test, UCRL-ID-147023: Livermore, Calif., Lawrence Livermore National Laboratory, 507 p.

Prothro, L.B., and Drellack, S.L., 1997, Nature and extent of lava-flow aquifers beneath Pahute Mesa, Nevada Test Site: Bechtel Nevada DOE/NV/11718-156, prepared for the U.S. Department of Energy Nevada Operations Office, $50 \mathrm{p}$.

Prothro, L.B., Drellack, S.L., and Mercadente, J.M., 2009, A hydrostratigraphic system for modeling groundwater flow and radionuclide migration at the corrective action unit scale, Nevada test site and surrounding areas, Clark, Lincoln, and Nye Counties, Nevada: National Security Technologies, LLC, DOE/NV/25946-630, prepared for the U.S. Department of Energy Nevada Operations Office, 145 p.

Sawyer, D.A., Fleck, R.J., Lanphere, M.A., Warren, R.G., Broxton, D.E., and Hudson, M.R., 1994, Episodic caldera volcanism in the Miocene southwestern Nevada volcanic field-Revised stratigraphic framework, ${ }^{40} \mathrm{Ar} /{ }^{39} \mathrm{Ar}$ geochronology, and implications for magmatism and extension: Geological Society of America Bulletin, v. 106, p. 1,304-1,318.

Slate, J.L., Berry, M.E., Rowley, P.D., Fridrich, C.J., Morgan, K.S., Workman, J.B., Young, O.D., Dixon, G.L., Williams, V.S., McKee, E.H., Ponce, D.A., Hildenbrand, T.G., Swadley, W.C., Lundstrom, S.C., Ekren, E.B., Warren, R.G., Cole, J.C., Fleck, R.J., Lanphere, M.A., Sawyer, D.A., Minor, S.A., Grunwald, D.J., Laczniak, R.J., Menges, C.M., Yount, J.C., and Jayko, A.S., 2000, 
Digital geologic map of the Nevada test site and vicinity, Nye, Lincoln, and Clark Counties, Nevada, and Inyo County, California: U.S. Geological Survey Open-File Report 99-554A, 53 p.

Stoller-Navarro Joint Venture, 2004, Hydrologic data for the groundwater flow and contaminant transport model of corrective action units 101 and 102 - Central and western Pahute Mesa, Nye County, Nevada: Stoller-Navarro Joint Venture report S-N/99205-02, revision no. 0., prepared for U.S. Department of Energy, 422 p.

Strebelle, Sebastien, 2000, Sequential simulation drawing structures from training images: Stanford University, Ph.D. dissertation, 187 p.

Strebelle, Sebastien, 2002, Conditional simulation of complex geological structures using multiple-point statistics: Mathematical Geology, v. 34, no. 1, p. 1-21.

U.S. Geological Survey, 2014, USGS/U.S. Department of Energy Cooperative Studies in Nevada: U.S. Geological Survey, accessed February 6, 2014, at http://nevada.usgs.gov/doe_nv/.

Walker, G.P.L., 1973, Lengths of lava flows: Philosophical Transactions of the Royal Societies of London, Series A, Mathematical and Physical Sciences, v. 274, no. 1238, p. 107-118. 